\title{
PERANCANGAN PEMBELAJARAN VIRTUAL OVOP SEBAGAI SARANA PENGEMBANGAN ILMU EKONOMI DI ERA DISRUPSI
}

\author{
Emma Yunika Puspasari $^{1^{*}}$ \\ ${ }^{1}$ Universitas Negeri Malang \\ 1emma.yunika.fe@um.ac.id
}

\begin{abstract}
Hegemony classical in economics raises the prisoner's dilemma related to the ever-changing paradigm of disruption education. Overcoming this dilemma requires a choice of orientation for the Virtual OVOP design, which determines the commitment to resolve the disruption of education polemic. The learning innovation projected was the design of Virtual OVOP learning as a means of developing economics. The affirmation of the concept of economic learning between central and peripheral had been demonstrated by classical economics', which magnum opus. We should fossilize it in the frame of cultural awareness to exploit the local potential. The idealization of the existence of learning through exploiting the economic potential in the spirit of trying to be together in mainstream education can be realized more clearly with the Virtual OVOP learning design. Learning virtual OVOP using the research and development model approach is a One Village One Product (OVOP) model that was part of learning based on educational videos and animated multimedia on mapping feature products of a rural area and the efficient use of local resources to build a welfare rural.
\end{abstract}

Keywords: Virtual OVOP, Educative Video, Welfare Rural

\section{Pendahuluan}

Mendiskusikan perihal entitas pendidikan perguruan tinggi saat ini, dalam kaitannya dengan era disrupsi dalam dunia pendidikan dan pembelajaran ekonomi, kiranya salah satu kritikal poin yang mendasar adalah pada segmentasi substansi dialektika pendidikan mainstream dari pilihan orientasi pengembangan potensi ekonomi bangsa, yang selama ini begitu dirasakan timpang. Pada titik ini, sebenarnya pendidikan ekonomi seolah terkena sindrom idopatis secara filosofis, tidak memiliki sense of reality dan sense of history. Beranjak dari hal tersebut, kiranya sangatlah urgen dan relevan apabila para stakeholder di perguruan tinggi melakukan upaya konfiguratif untuk bersinergi mendorong peningkatan kualitas pendidikan ekonomi yang bercirikan penguatan ekonomi lokal.

Dalam konteks inilah, penulis mencoba membangun pendekatan dalam paradigma baru disrupsi, yakni sudah saatnya memberikan pola yang berbeda di era disrupsi ini, menggantikan paradigma pendidikan klasik yang selama ini menjadi pembelajaran mainstream. Pendidikan ideal yang didukung dengan sarana teknologi yang sangat memadai di era disrupsi ini sebenarnya haruslah diimbangi dengan kemampuan dosen untuk mengelola kelas perkuliahan yang inovatif (Puspasari, 2017:2) Inovasi pembelajaran yang diproyeksikan adalah perancangan Virtual OVOP sebagai sarana pengembangan pembelajaran ekonomi. Peneguhan konsep pembelajaran ekonomi antara pusat dan pinggiran, sebagaimana yang telah dihegemonikan oleh pendidikan global selama ini, sudah seharusnya kita fosilkan dalam bingkai kesadaran kultural untuk memanfaatkan potensi ekonomi lokal, sehingga idealisasi akan eksistensi pembelajaran melalui pemanfaatan potensi ekonomi lokal dalam semangat untuk mencoba secara bersama di tengah aliran pendidikan maintream arus utama akan dapat direalisasikan secara lebih nyata dengan rancangan pembelajaran Virtual Ovop.

DOI: 10.33603/ejpe.v8i2.3999 
Pilihan orientasi perancangan pembelajaran Virtual Ovop ini menentukan komitmen untuk menyelesaikan polemik pendidikan ekonomi di era disrupsi ini sangat diperlukan khususnya untuk pengembangan perkuliahan ekonomi kerakyatan. Berbicara mengenai pengembangan pembelajaran ekonomi kerakyatan salah satunya adalah membangun ekonomi kawasan pinggiran dengan memperkuat desa dalam kerangka negara kesatuan (Puspasari, et all 2019:2). Hal ini merupakan salah satu wujud tercapainya tujuan pembelajaran ekonomi kerakyatan. Pengembanagan video edukasi Virtual Ovop merupakan rancangan mengenai rekayasa video edukasi mengenai ekonomi rakyat berbasis potensi lokal, membangun satu desa satu komoditas berdasarkan keunggulan komparatifnya dengan memanfaatkan sumber daya lokal secara efisien. OVOP sebenarnya merujuk dari salah satu kebijakan taktis dalam pembangunan desa. OVOP memiliki kerangka kerja untuk mengeksplorasi potensi dan mengembangkan cara desa dalam menjaga serta mengembangkan asset ekonomi, hanya saja dalam research pengembangan yang dilakukan oleh penulis ini berupaya untuk mensimulasikan cara desa dalam membangun potensi ekonomi lokal yang diaktualisasikan pada kondisi riil.

Video edukasi virtual OVOP merupakan bagian dari media pembelajaran berbasis multimedia. Video edukasi merupakan salah satu media pembelajaran yang menyenangkan bagi mahasiswa. Menurut Munir (2012: 289), "Video adalah teknologi penangkapan, perekaman, pengolahan, dan penyimpanan, pemindahan, dan perekonstruksian urutan gambar diam dengan menyajikan adegan-adegan dalam gerak secara elektronik". Dalam pemilihan pengembangan video edukasi ini juga memperhatikan pendapat dari Gerlack dan Ely dalam Asyhar (2012: 83-84) yang memberikan lima prinsip pemilihan media antara lain kesesuaian, kejelasan sajian, kemudahan akses, keterjangkauan, ketersediaan, kualitas, adanya alternatif, interaktif, organisasi, kebaruan, dan berorientasi pada mahasiswa. Hal tersebut juga sejalan dengan pernyataan Indaryati \& Jailani (2015:88) proses pembelajaran yang menyenangkan dapat memudahkan siswa dalam meningkatkan motivasi belajarnya dan prestasi belajar khususnya aspek kognitif.

Pemanfaatan media pembelajaran berbasis video edukasi belum dimanfaatkan pada mata kuliah ekonomi kerakyatan. Padahal penggunaan multimedia tersebut terdapat efek visual yang dapat menghasilkan video edukasi menarik. Maka dari itu penggunaan media pembelajaran berbasis video edukasi virtual OVOP diharapkan lebih membantu mahasiswa dalam memahami materi yang disampaikan oleh dosen. Media pembelajaran dirancang lebih menarik sehingga mahasiswa kosentrasi ekonomi kerakyatan dapat menggunakan media tersebut secara mandiri ketika diluar jam perkuliahan ekonomi kerakyatan.Dengan demikian, multimedia pembelajaran yang dikembangkan telah dimanfaatkan secara tepat diharapkan bisa memberi manfaat yang sangat besar dalam proses perkuliahan ekonomi kerakyatan.

\section{Metode Penelitian}

Rancangan Pengembangan inovasi pembelajaran ini menggunakan pendekatan penelitian pengembangan (Research \& Development). Penelitian pengembangan ini merupakan metode penelitian yang digunakan untuk menghasilkan produk video edukasi, lalu melakukan pengujian terhadap produk pembelajaran video edukasi tersebut. Apabila nilai dari hasil pengujian itu baik, maka produk tersebut layak untuk diedarkan di kalangan masyarakat. Jenis penelitian ini adalah penelitian pengembangan (Research \& Development) yang menggunakan model ADDIE. Model ADDIE (Analysis-Design-Develop-ImplementEvaluate) merupakan model pembelajaran yang bersifat generik dan sesuai untuk research pengembangan di pendidikan tinggi. ADDIE dikembangkan oleh Reiser dan Mollenda, 
menurut Reiser.et.all (2003:15) model ini sering digunakan untuk menggambarkan pendekatan sistematis dalam pengembangan instruksional. Selain itu, Molenda juga mengatakan bahwa ADDIE merupakan model pembelajaran yang umum dan sesuai untuk penelitian pengembangan (Molenda, 2003:17). Ketika digunakan dalam research pengembangan, ADDIE ini dianggap berurutan dan juga interaktif (Molenda,2003:18)

Hal ini sejalan dengan pendapat Mulyati ningsih (2011:5) yang menyatakan bahwa ADDIE adalah model yang dianggap lebih rasional dan lebih lengkap dibandingkan dengan model pengembangan lain. Berdasarkan hal tersebut dapat dinyatakan bahwa ADDIE dapat diproyeksikan untuk pengembangan produk pembelajaran di pendidikan tinggi meliputi model, strategi pembelajaran, metode pembelajaran, media dan bahan ajar.

Tujuan dari penelitian ini adalah untuk menghasilkan produk dan kelayakan produk pembelajaran yang dikembangkan kemudian menguji coba produk yang dihasilkan berupa video edukasi Virtual Ovop. Produk video edukasi pembelajaran dikembangkan sesuai dengan prosedur metode pengembangan ADDIE (Analysis, Design, Development, Implementation, Evaluation) yang dimodifikasi dari Robert Maribe Branch (2009:21) yang dikolaborasikan dengan Reigeluth tentang Taksonomi Variabel Pembelajaran. Uji coba Video Virtual OVOP ini diproyeksikan pada mahasiswa konsentrasi ekora, sedang menempuh mata kuliah ekonomi kerakyatan yang diampu oleh penulis.

Prosedur penelitian pengembangan video edukasi "Virtual Ovop" ini terdiri dari lima fase yang dikembangkan yaitu 1) Analysis, a) analisis tujuan dan karakteristik bidang keilmuan; b) analisis metode penyampaian dan kendala bidang keilmuan; c) analisis karakteristik mahasiswa. 2) Design, a) content; b) naskah; c) instrument. 3) Development, a) pengembangan produk; b) review ahli; c) pilot test. 4) Imlementation, a) menyiapkan mahasiswa dan dosen; b) uji coba pemakaian. 5) Evaluation, a) evaluasi formatif; b) evaluasi sumatif. Produk video yang dikembangkan sesuai dengan prosedur metode pengembangan ADDIE yang dimodifikasi dari Robert Maribe Branch (2009:27) yang dikolaborasikan dengan Reigeluth tentang Taksonomi Variabel Pembelajaran. Lima fase pengembangan video edukasi Virtual OVOP tersebut mengadopsi model pengembangan ADDIE yang tahapannya dapat dijelaskan secara konfiguratif di bawah ini

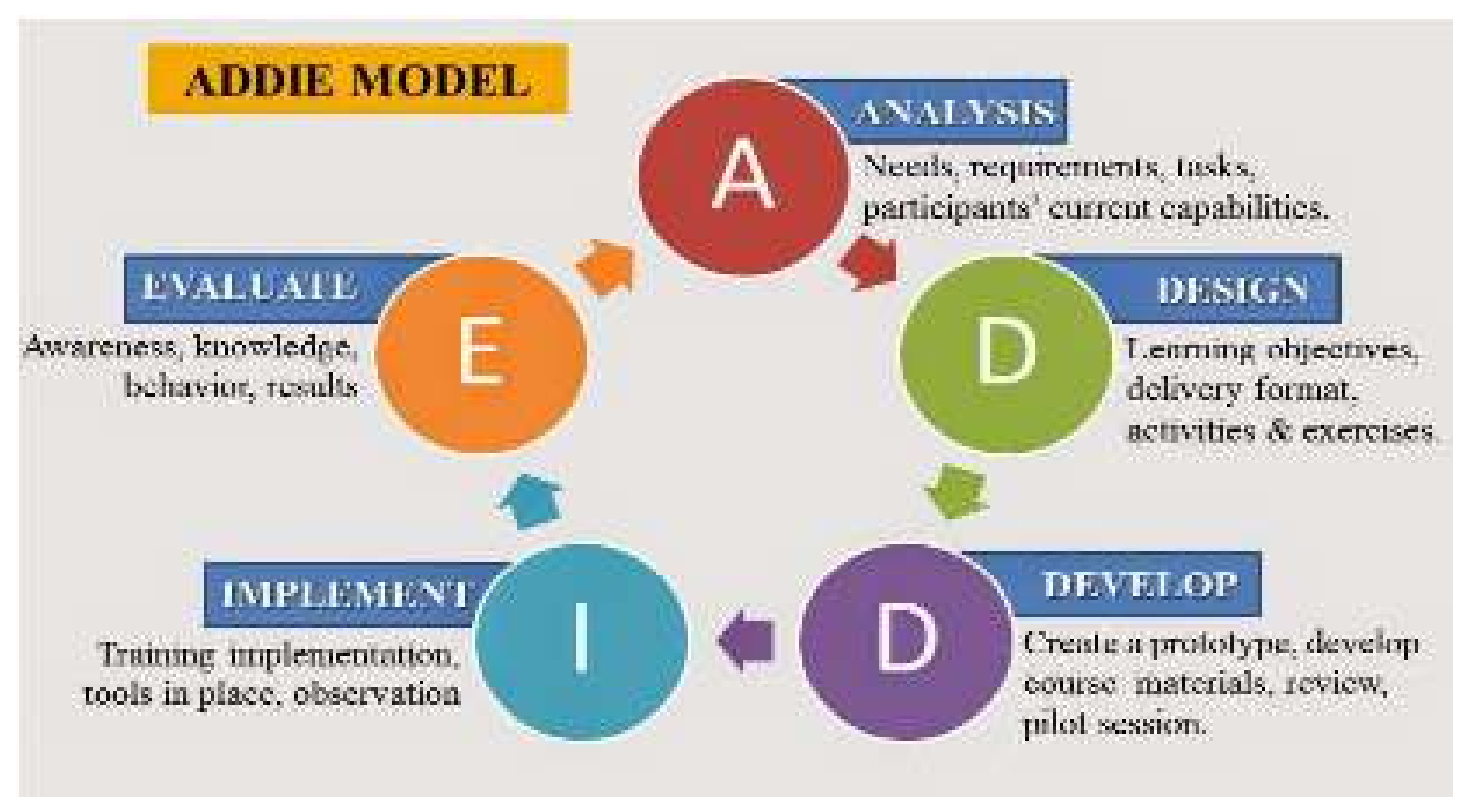

Gambar 1. Pengembangan ADDIE Model 
Sumber: mengadopsi Maribe Branch\&Reigeluth yang dimodifikasi

Berdasarkan gambar 1 tersebut dapat dijelaskan alur kronologis dari tiap fase pengembangan yang diterapkan dalam research ini sebagai berikut :

\section{Fase Analisis}

Pada fase analisis dalam research pengembangan ini terbagi menjadi dua tahap, yaitu analisis kinerja atau performance analysis dan analisis kebutuhan (need analysis). Tahap pertama, yaitu analisis kinerja dilakukan untuk mengetahui dan mengklarifikasi apakah masalah dalam proses perkuliahan ekonomi kerakyatan yang dihadapi oleh mahasiswa memerlukan solusi. Pada tahap kedua, yaitu analisis kebutuhan, merupakan langkah yang diperlukan untuk menentukan kemampuan - kemampuan atau kompetensi yang perlu dipelajari oleh mahasiswa ekonomi kerakyatan untuk meningkatkan hasi belajar dalam perkuliahan ekonomi kerakyatan

\section{Fase Desain}

Pada fase ini tindakan yang dilakukan adalah membuat rancang bangun (blueprint) desain pengembangan. Dalam research pengembangan ini langkah pertama yang dilakukan adalah merumuskan tujuan perkuliahan yang SMAR (spesifik, measurable, applicable, dan realistic). Selanjutnya menyusun tes, dimana tes tersebut harus didasarkan pada tujuan pembelajaran yag telah dirumuskan tadi. Kemudian menentukan strategi pembelajaran yang tepat untuk mata kuliah ekonomi kerakyatan. Disamping itu, penulis juga mempertimbangkan sumber-sumber pendukung lain, semisal sumber belajar yang relevan, lingkungan belajar yang seperti apa seharusnya. Semua itu tertuang dalam suatu dokumen bernama blueprint desain pengembangan virtual OVOP yang jelas dan rinci.

\section{Fase Pengembangan}

Pada fase ini, penulis melakukan proses mewujudkan blueprint alias desain video edukasi virtual OVOP menjadi kenyataan. Artinya, jika dalam desain diperlukan suatu software berupa multimedia pembelajaran, maka multimedia tersebut harus dikembangkan. Begitu pula halnya dengan lingkungan belajar dalam kuliah ekonomi kerakyatan yang akan mendukung proses perkuliahan semuanya dipersiapkan dalam fase ini. Satu langkah penting dalam fase pengembangan adalah uji coba sebelum diimplementasikan. Tahap uji coba ini memang merupakan bagian dari salah satu langkah ADDIE model, yaitu evaluasi. Lebih tepatnya dalam research ini menggunakan evaluasi formatif, karena hasilnya digunakan untuk memperbaiki sistem perkuliahan ekonomi kerakyatan yang sedang dikembangkan.

\section{Fase Implementasi}

Pada fase implementasi atau penyampaian materi perkuliahan ekonomi kerakyatan merupakan langkah keempat dari model desain ADDIE. Langkah implementasi sering diasosiasikan dengan penyelenggaraan program perkuliahan itu sendiri. Langkah ini memang mempunyai makna adanya penyampaian materi perkuliahan dari dosen kepada mahasiswa.

Tujuan utama dari fase implementasi, yang merupakan langkah realisasi desain dan pengembangan dalam mata kuliah ekonomi kerakyatan adalah sebagai berikut:

1. Membimbing mahasiswa untuk mencapai tujuan perkuliahan sesuai SCPL dan CPMK yang termuat dalam RPS mata kuliah ekonomi kerakyatan. 
2. Menjamin adanya pemecahan masalah atau solusi untuk mengatasi kesenjangan hasil belajar yang dihadapi oleh mahasiswa.

3. Memastikan bahwa pada akhir program perkuliahan ekonomi kerakyatan, mahasiswa perlu memiliki kompetensi pengetahuan, keterampilan, dan sikap yang diperlukan dalam pengembangan ekonomi kerakyatan

\section{Fase Evaluasi}

Fase terakhir atau kelima dari model ADDIE adalah evaluasi. Evaluasi pengembangan mulitimedia berbasis video edukasi dalam mata kuliah ekonomi kerakyatan ini dapat diredefinisikan sebagai sebuah proses yang dilakukan untuk memberikan nilai terhadap program perkuliahan ekonomi kerakyatan.. Pada dasarnya, evaluasi dapat dilakukan sepanjang pelaksanaan kelima langkah dalam model ADDIE. Pada langkah analisis misalnya, proses evaluasi dilaksanakan dengan cara melakukan klarifikasi terhadap kompetensi pengetahuan, keterampilan, dan sikap yang harus dimiliki oleh mahasiswa setelah mengikuti perkuliahan ekonomi kerakyatan. Evaluasi dalam research pengembangan ini menggunakan evaluasi formatif.

Evaluasi terhadap perkuliahan ekono mi kerakyatan ini bertujuan untuk mengetahui beberapa hal, antara lain

1. Sikap mahasiswa terhadap kegiatan perkuliahan secara keseluruhan,

2. Peningkatan kompetensi mahasiswa yang merupakan dampak dari keikutsertaan dalam proses perkuliahan ekonomi kerakyatan, dan

3. Keuntungan yang dirasakan oleh program kosentrasi ekonomi kerkyatan akibat adanya peningkatan kompetensi mahasiswa setelah mengikuti perkuliahan ekonomi kerakyatan.

\section{Hasil dan Pembahasan}

\section{Pengembangan video edukasi virtual OVOP dengan ADDIE model}

Secara konfiguratif hasil pengembangan video edukasi OVOP pada perkuliahan ekonomi kerakyatan disintesakan dalam peta fase perkembangan vitual OVOP yang terkonstruksi dari lima fase pengembangan berikut: 


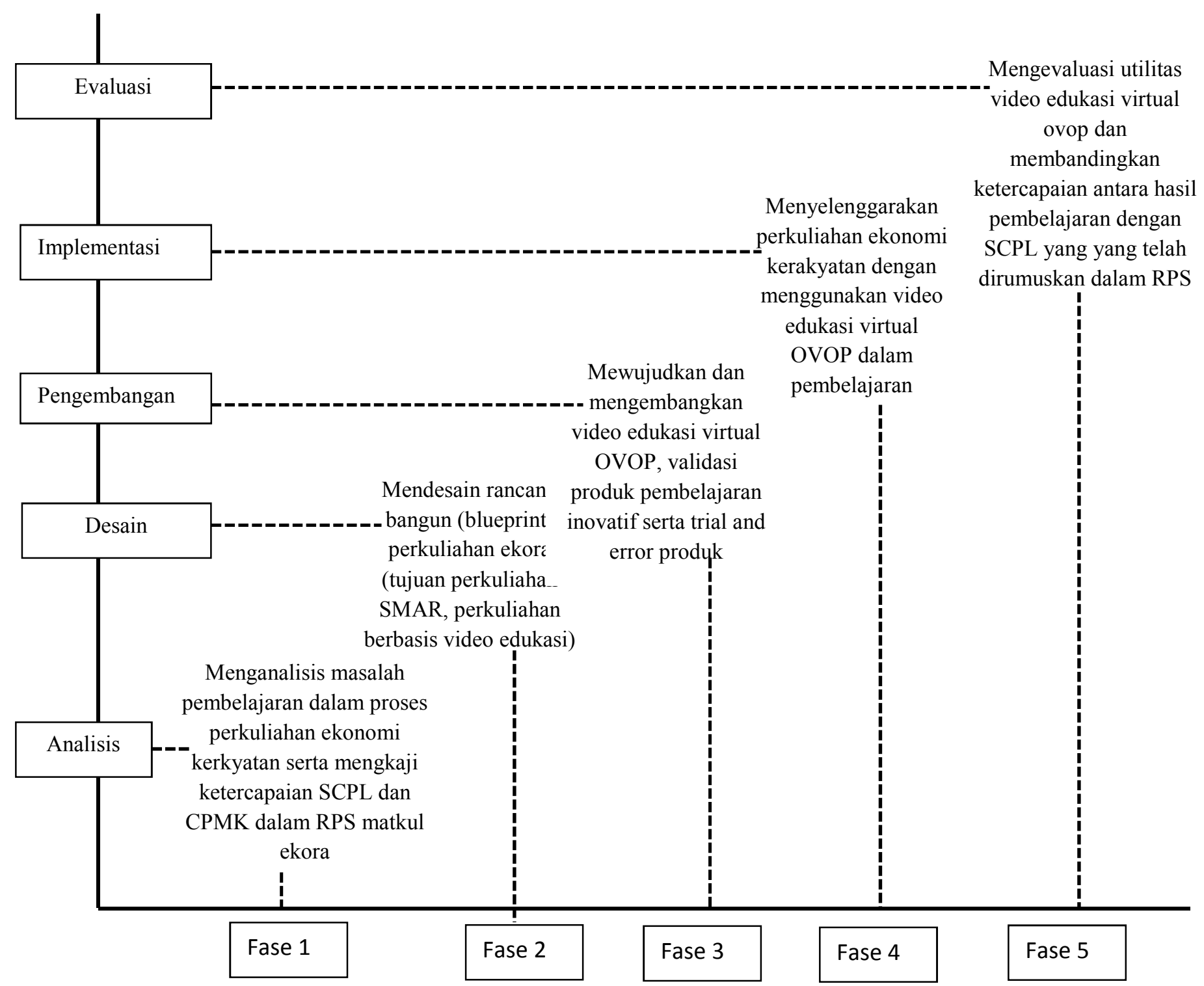

Gambar 2. Peta Fase Alur Desain Pengembangan Virtual OVOP

\section{Sumber: direkonstruksi peneliti berdasarkan data lapangan}

Berdasarkan paparan konfiguratif dari desain pengembangan yang ditampilkan dalam gambar 2 tersebut, secara kronologis dapat dijelaskan sebagai berikut:

\section{Fase Analisis (Analysis)}

Berdasarkan alur research pengembangan ini pada fase analisis terdiri atas dua tahap, yaitu analisis kinerja dan analisis kebutuhan. Analisis kinerja dalam penelitian ini bertujuan untuk mengetahui dan mengklasifikasikan masalah dasar pembelajaran dalam proses

$$
\text { p-ISSN 2337-571X | e-ISSN 2541-562X }
$$


perkuliahan ekonomi kerakyatan. Solusi dari permasalahan perkuliahan tersebut bisa dilakukan dengan cara penyediaan fasilitas pembelajaran yang memadai, misalnya tersedia media dan bahan ajar ekonomi kerakyatan yang update. Langkah kedua adalah Analisis kebutuhan yang merupakan langkah untuk menentukan kemampuan atau kompetensi yang perlu dipelajari oleh mahasiswa untuk meningkatkan pengetahuan mengenai produk unggulan dan potensi lokal desa dalam kajian ekonomi kerakyatan. Berdasarkan hasil analisis dan pengamatan penulis saat mengajar mahasiswa kosentrasi ekonomi kerakyatan diketahui bahwa kompetensi yang akan dicapai mahasiswa setelah mengikuti perkuliahan ekonomi kerakyatan adalah sesuai dengan tujuan dari Silabus dan SAP Ekonomi Kerakyatan.

\section{Fase Perancangan (Design)}

Pada fase ini, penulis membuat rancangan (blueprint) dalam pengembangan perkuliahan ekonomi kerakyatan. Dalam fase ini, penulis memualai dengan merumuskan tujuan pembelajaran yang SMAR (spesifik, measurable, applicable, dan realistic) sesuai dengan SCPL dan CPMK dalam RPS ekonomi kerakyatan. Kemudian disusun bahan ajar perkuliahan ekonomi kerakyatan dan desain produk, sebagai berikut: Menyusun kerangka struktur, yang dilakukan adalah menganalisis materi yang ditampilkan, menganalisis desain tampilan, menentukan soal evaluasi, perancangan konsep media, pemilihan rancangan desain. Menentukan sistematika pengembangan media, didasarkan pada penjabaran Silabus dan SAP mata kuliah ekonomi kerakyatan. Naskah, materi, ilustrasi, visualisasi dan bahan animasi yang akan digunakan diambil dari sumber-sumber yang relevan. Halaman ini terdiri dari beberapa layar yang ditampilkan secara urut mulai dari awal hingga akhir materi.Merancang alat evaluasi berupa instrumen, instrumen yang digunakan adalah jenis angket atau chek list yang diberikan kepada ahli media, ahli materi maupun dosen pendidikan ekonomi dan mahasiswa sebagai subjek penelitian. Lembar validasi untuk ahli media, ahli materi maupun dosen ekonomi berbentuk chekc list

\section{Fase Pengembangan (Development)}

Pada langkah pengembangan (Development) dikembangkan bahan ajar video edukasi Virtual OVOP, kemudian melakukan validasi ahli dan revisi produk. Pada fase 3 ini, 3 validator dipilih sebagai validator ahli media. Aspek penilaian secara menyeluruh diperoleh penilaian $86,08 \%$ yang termasuk dalam kualifikasi sangat baik, sehingga video edukasi virtual OVOP ini layak digunakan dalam perkuliahan ekonomi kerakyatan. Mengembangkan video edukasi yang dapat dikategorikan layak untuk digunakan sebagai multimedia video perkuliahan ekonomi kerakyatan berdasarkan skala prosentase kelayakan. Hal ini mengacu pada data yang diolah bahawa menyajikan informasi secara visual dan audio secara baik mampu membatu pemahaman mahasiswa ternyata sesuai dengan yang dikemukan oleh Riyana (2007:2) bahwa media video edukasi merupakan media yang menyajikan audio visual yang berisi pesan-pesan pembelajaran baik berisi konsep, prinsip, prosedur, teori, aplikasi yang dapat membantu pemahaman mahasiswa dalam perkuliahan.

\section{4. $\quad$ Fase Implementasi (Implementation)}

Pada fase ini diimplementasikan rancangan dan metode yang telah dikembangkan pada situasi perkuliahan ekonomi kerakyatan di kelas. Selama implementasi, rancangan produk vide edukasi virtual OVOP yang telah dikembangkan diterapkan pada mahasiswa kosentrasi ekonomi kerakyatan di kelas. Berdasarkan hasil data yang diolah, perkuliahan dengan video edukasi virtual OVOP yang menceritakan membangun desa dengan produk

\footnotetext{
$p-I S S N \underline{2337-571 X} \mid$ e-ISSN $\underline{2541-562 X}$

(C) 2020 Edunomic: Jurnal Ilmiah Pendidikan Ekonomi Fakultas Keguruan dan Ilmu Pendidikan
} 
unggulan dan potensi lokal daerah serta memanfaatkan sumber daya lokal secara efisien ternyata efektif digunakan dalam perkuliahan ekonomi kerakyatan.

\title{
5. Fase Evaluasi (Evaluation)
}

Pada fase evaluasi ini dilakukan untuk menganalisis kelayakan dan keefektifan video edukasi virtual OVOP yang dikembangkan pada tahap implementasi serta melakukan revisi produk berdasarkan evaluasi pada saat ujicoba lapangan. Data-data yang telah dianalisis untuk mengetahui revisi yang perlu dilakukan serta mengevaluasi kembali kelayakan produk pembelajaran berupa video edukasi virtual OVOP efektif digunakan dalam perkuliahan ekonomi kerakyatan.

Merujuk pada pendapat Brame (2016:4), video sebagai mediapembelajaran akan efektif jika dapat meminimalkan usaha kognitif yang tidak mendukung peningkatan hasil belajar mahasiswa, serta mengoptimalkan aktifitas kognitif yang mendukung peningkatan hasi belajar pada mahasiswa. Apabila decermati secara seksama pendapat tersebut, maka video edukasi virtual OVOP mendapatkan ruang keunikan tersendiri disbanding dengan multimedia lainnya, yang bisa dijabarkan secara konfiguratif dalam gambar 3 berikut :

\begin{tabular}{cc}
\hline Video edukasi virtual OVOP & $\begin{array}{c}\text { Utilitas rasional penggunaan } \\
\text { video virtual OVOP }\end{array}$ \\
\hline $\begin{array}{c}\text { Signalling } \\
\text { (menekankan pada informasi penting) }\end{array}$ & $\begin{array}{c}\text { menekankan pada informasi } \\
\text { penting, tidak banyak penggunaan } \\
\text { warna pada materi }\end{array}$ \\
\hline $\begin{array}{c}\text { Segmenting } \\
\text { (memotong informasi yang tidak berhubungan } \\
\text { dengan konten materi) }\end{array}$ & $\begin{array}{c}\text { Durasideo } \\
\text { Weeding }\end{array}$ \\
$\begin{array}{c}\text { (penghapusan informasi yang tidak penting) } \\
\text { Matching modality } \\
\text { (penggunaan audio visual) }\end{array}$ & $\begin{array}{c}\text { Mengurangi penggunaan music dan } \\
\text { latar gambar yang berlebihan }\end{array}$ \\
\hline & $\begin{array}{c}\text { Penggunaan audio visual dan } \\
\text { kondisi riil yang menjelaskan suatu } \\
\text { fenomena pada konten terkait }\end{array}$ \\
\hline
\end{tabular}

Gambar 3. Keunggulan video edukasi virtual OVOP

Sumber: direkonstruksi peneliti berdasarkan adaptasi kerangka dimensi Brame

\section{Simpulan}

Berdasarkan hasil analisis yang telah dipaparkan secara kronologis dan konfiguratif rancangan video edukasi virtual OVOP dengan pendekatan pengembangan model ADDIE memiliki kelebihan media video antara lain, menyampaikan pesan yang dapat dipahami secara lebih baik oleh mahasiswa kosentrasi ekonomi kerkyatan, sangat baik untuk menjelaskan/menerangkan suatu proses mengenai membangun desa dengan keunggulan produk dan potensi lokal dengan memanfaatkan sumberdaya lokal yang efisien. Video edukasi Virtual OVOP memenuhi kriteria baik sebagai media dalam kuliah mandiri Penggunaan media pembelajaran berbasis video edukasi virtual OVOP yang dimanfaatkan pada mata kuliah ekonomi kerakyatan memiliki keunikan tersendiri apabila disesuaikan dengan konten materi ekonomi kerakyatan. Penggunaan multimedia tersebut terdapat efek

\author{
p-ISSN 2337-571X | e-ISSN $\underline{\text { 2541-562X }}$ \\ (C) 2020 Edunomic: Jurnal Ilmiah Pendidikan Ekonomi \\ Fakultas Keguruan dan Ilmu Pendidikan
}


visual yang dapat menghasilkan video edukasi menarik. Maka dari itu penggunaan media pembelajaran berbasis video edukasi virtual OVOP sangat membantu mahasiswa dalam memahami materi yang disampaikan oleh dosen. Media pembelajaran dirancang lebih menarik sehingga mahasiswa kosentrasi ekonomi kerakyatan dapat menggunakan media tersebut secara mandiri ketika diluar jam perkuliahan ekonomi kerakyatan.Dengan demikian, multimedia pembelajaran yang dikembangkan telah dimanfaatkan secara tepat ini ternyata bisa memberi manfaat yang sangat besar dalam proses perkuliahan ekonomi kerakyatan.

Berdasarkan simpulan tersebut video edukasi saat ini masih perlu dikembangkan salah satunya dengan pemanfaatan video edukasi virtual OVOP yang dimaksudkan agar mahasiswa lebih mudah memahami perkuliahan ekonomi kerakyatan sehingga menarik minat mahasiswa dan tercipta perkuliahan yang lebih efektif dan efisien serta meningkatkan kualitas belajar mahasiswa dan dapat belajar secara mandiri mengenai langkah taktis desa memetakan dan mengembangkan produk unggulan dalam kajian ekonomi kerakyatan karena dapat diputar secara berulang-ulang sampai mahasiswa paham.

\section{Referensi}

Brame,C.J.(2016). Effective education videos: principles and guidelines maximizing student learning video content. CBE life sciences education, 15(4) es6 (PDF) Desain Video Pembelajaran Yang Efektif Pada Pendidikan Jarak Jauh: Studi Di Universitas Terbuka.

Branch, R.M., (2009). Instructional Design : The ADDIE Approach. New York: Springer Science Business Media

Li. Y. J. \& Shieh. J. C. (2015). A study on the effects of multiple goal orientation on learning motivation and learning behaviors. Eurasia Journal of Mathematics, Science \&Technology Education, 12(1), 161-172

Molenda, M. 2003. In search of the ellusive ADDIE model. Performance improvement, 42 (5), 34-36. Submitted for publication in A. Kovalchick \& K. Dawson.Eds.Educational Technologi: An Encyclopedia.

Munir. 2012. Multimedia : Konsep \& Aplikasi dalam Pendidikan. Bandung : Alfabeta. Indaryati, I., \& Jailani, J. (2015). Pengembangan media komik pembelajaran matematika meningkatkan motivasi dan prestasi belajar siswa kelas V. Jurnal Prima Edukasia, 3(1), 84-96. Retrieved from http://journal.uny.ac.id/index.php/jpe/article/view/4067/3521

Muvawala, J. (2012). Determinants of learning outcomes for primary education: A case of Uganda. Journal Statistique Africain. 15. 42-54 Santrock, J. W. (2011). Psikologi pendidikan.

Puspasari, E.Y.2017. Action research: Enhancing Classroom Practice and FulfillingLearning Responsibilities with Guided Note Taking (GNT) and Teams Games Tournament (TGT) Models. Classroom Action Research Journal, 1(1), 36-42

Puspasari,E.Y et.all (2019). Prosiding SENADIMAS Ke-4, Tahun 2019ISBN 987-623-748200-0.Seminar Nasional Pengabdian kepada Masyarakat, 2019

Sonmez, D. \& Can, M. H. (2012). Videos as an instructional tool in pre service science teacher education. Eurasian Journal of Education Research, 46, 141-158.

Susilana, R. (2008). Media pembelajaran. Bandung: Universitas Pendidikan Indonesia

Woo, C. J. (2014). Digital game based learning support student motivation, cognitive success, and performance outcomes.

Riyana, C. (2007). Pedoman Pengembangan Media Video. Bandung: Universitas Pendidikan Indonesia

p-ISSN 2337-571X | e-ISSN 2541-562X

(C) 2020 Edunomic: Jurnal Ilmiah Pendidikan Ekonomi Fakultas Keguruan dan Ilmu Pendidikan 